\title{
Summary of Pellet Technology Program Activities
}

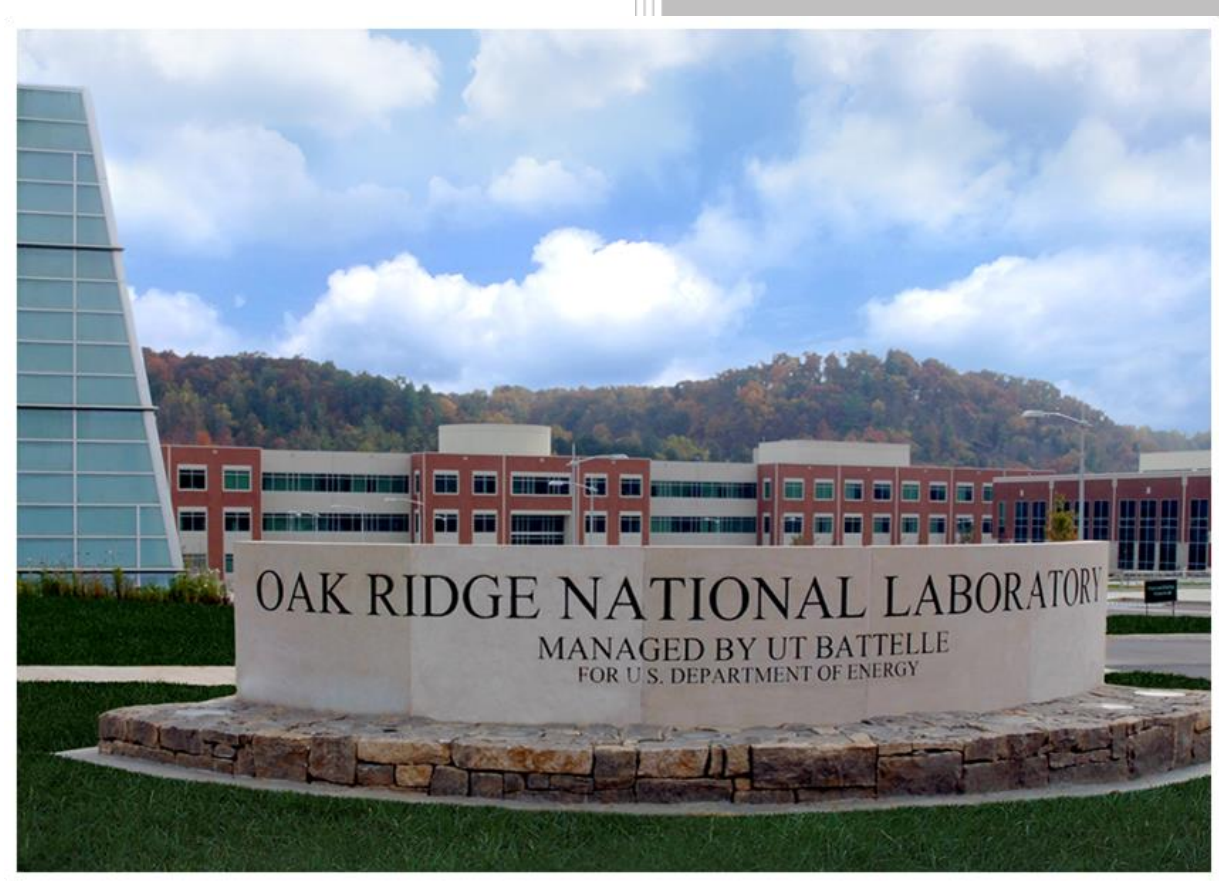

\section{Plasma Enabling Technology (base program)}

L. R. Baylor, Principal Investigator

G. L. Bell, FWP Manager

Barry Sullivan, Federal Program Manager, Office of Fusion Energy Sciences
T. E. Gebhart
L. R. Baylor
G. L. Bell
S. J. Meitner

May 2, 2018

Approved for public release. Distribution is unlimited. 


\title{
DOCUMENT AVAILABILITY
}

Reports produced after January 1, 1996, are generally available free via US Department of Energy (DOE) SciTech Connect.

Website www.osti.gov

Reports produced before January 1, 1996, may be purchased by members of the public from the following source:

\author{
National Technical Information Service \\ 5285 Port Royal Road \\ Springfield, VA 22161 \\ Telephone 703-605-6000 (1-800-553-6847) \\ TDD 703-487-4639 \\ Fax 703-605-6900 \\ E-mailinfo@ntis.gov \\ Website http://classic.ntis.gov/
}

Reports are available to DOE employees, DOE contractors, Energy Technology Data Exchange representatives, and International Nuclear Information System representatives from the following source:

Office of Scientific and Technical Information

PO Box 62

Oak Ridge, TN 37831

Telephone 865-576-8401

Fax 865-576-5728

E-mail reports@osti.gov

Website http://www.osti.gov/contact.html

This report was prepared as an account of work sponsored by an agency of the United States Government. Neither the United States Government nor any agency thereof, nor any of their employees, makes any warranty, express or implied, or assumes any legal liability or responsibility for the accuracy, completeness, or usefulness of any information, apparatus, product, or process disclosed, or represents that its use would not infringe privately owned rights. Reference herein to any specific commercial product, process, or service by trade name, trademark, manufacturer, or otherwise, does not necessarily constitute or imply its endorsement, recommendation, or favoring by the United States Government or any agency thereof. The views and opinions of authors expressed herein do not necessarily state or reflect those of the United States Government or any agency thereof. 
Fusion and Materials for Nuclear Systems

\title{
SUMMARY OF PELLET TECHNOLOGY PROGRAM ACTIVITIES
}

\author{
T. E. Gebhart \\ L. R. Baylor \\ G. L. Bell \\ S. J. Meitner
}

Date Published: May 2, 2018

\author{
Prepared by \\ OAK RIDGE NATIONAL LABORATORY \\ Oak Ridge, TN 37831-6283 \\ managed by \\ UT-BATTELLE, LLC \\ for the \\ US DEPARTMENT OF ENERGY \\ under contract DE-AC05-00OR22725
}





\section{CONTENTS}

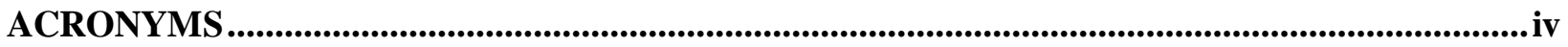

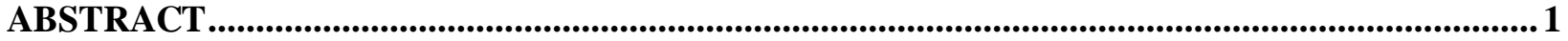

1. BUDGET SUMMARY AND JUSTIFICATION ...................................................................... 1

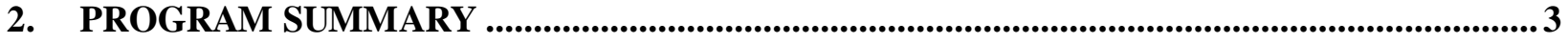

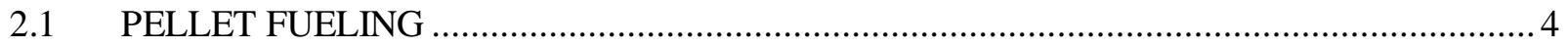

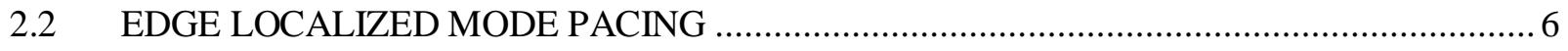

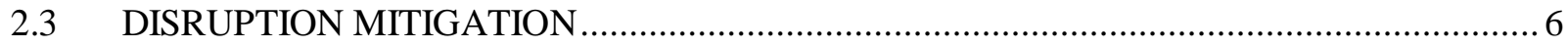

2.4 REFERENCES (CITED IN PROGRAM NARRATIVE .............................................. 8

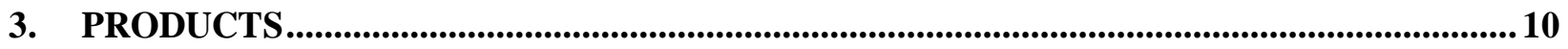

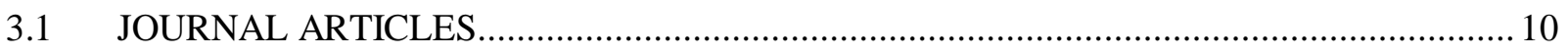

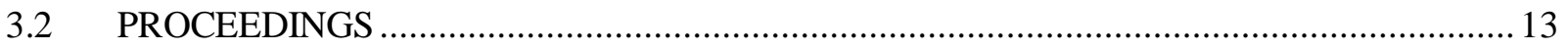

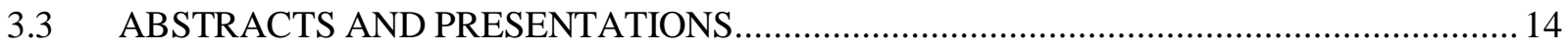

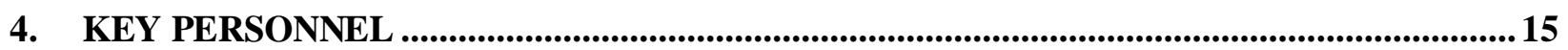

5. EQUIPMENT, FACILITIES AND OTHER RESOURCES ............................................. 18 


\section{ACRONYMS}

$\begin{array}{ll}\text { APS } & \text { American Physical Society } \\ \text { DEMO } & \text { DEMOnstration Power Station } \\ \text { DM } & \text { Disruption Mitigation } \\ \text { ELM } & \text { Edge Localized Mode } \\ \text { ENEA } & \text { Ente per le Nuove Technologie, l'Energia e l' Ambiente } \\ \text { ET } & \text { Electrothermal } \\ \text { FED } & \text { Fusion Energy Division } \\ \text { HFS } & \text { High Field Side } \\ \text { ITPA } & \text { International Tokamak Physics Activity } \\ \text { JET } & \text { Joint European Torus } \\ \text { LOCA } & \text { Loss of Coolant Accident } \\ \text { MAST } & \text { Mega-Amp Spherical Tokamak } \\ \text { MGI } & \text { Massive Gas Injection } \\ \text { MST } & \text { Madison Symmetric Torus } \\ \text { NFM } & \text { Nuclear Fuels and Materials Group } \\ \text { Proto-MPEX } & \text { Proto-Material Plasma Exposure eXperiment } \\ \text { R\&D } & \text { Research and Development } \\ \text { SPI } & \text { Shattered Pellet Injector } \\ \text { TFTR } & \text { Tokamak Fusion Test Reactor } \\ \text { TQ } & \text { Thermal Quench } \\ \text { TSE } & \text { Twin Screw Extruder } \\ \text { W7-AS } & \text { Wendelstein 7-AS } \\ \text { W7-X } & \text { Wendelstein 7-X }\end{array}$




\begin{abstract}
This report summarizes the activities and budget information of ORNL's pellet technology program from the start of FY2014 through FY2017. Cost summaries are broken down by year and spending category. Milestone activities are outlined and described by year and further described in the project narrative. The project narrative outlines the main pellet injection technology advances enabled by the pellet technology program. A list of published research products is included, along with biographies of personnel involved. This document was prepared in support of the April 24, 2018, review of the pellet technology program at ORNL.
\end{abstract}

\title{
1. BUDGET SUMMARY AND JUSTIFICATION
}

This program provides for advanced plasma fueling, disruption mitigation, and vacuum pumping system development in support of the U.S. Fusion Energy Sciences Program. As noted in the program narrative section, key activities include the development of innovative methods to enable the application of pellet technology for plasma fueling, disruption mitigation, and ELM mitigation experiments. While USITER, the International Collaboration Program (ERAT305), and the DIII-D Collaboration Program (ERAT355) pay the costs specific to their activities, e.g. design and fabrication of machine specific pellet injection systems like the shattered pellet injectors for Joint European Torus (JET) and DIII-D, these programs rely on the base program to support their mission. The support includes work to develop and prove out techniques and methods required to implement the technology needed to address physics goals and to provide the infrastructure required to assemble, test, and perform in lab commissioning prior to shipping completed systems to their destination experiment. Specific examples of enabling development include the development of shattered pellet technology (e.g. shell pellets, shatter tube optimization, punch development) for disruption mitigation, hardware and techniques to provide variable pellet sizing for fueling and ELM mitigation, high frequency pellet injection for ELM mitigation, continuous twin screw extruder development for steady state fueling, and high-speed pellet research and development (R\&D) for deep penetration in collaboration with Ente per le Nuove Technologie, l'Energia e l' Ambiente (ENEA)Frascati. The program also provides support for the necessary R\&D activities for ITER fueling, disruption and ELM mitigation systems.

Table 1 summarizes the Pellet Fueling Program costs for the reporting period, FY2014-2017. The labor cost comprises wage pool and organizational burden. Labor costs include support for researchers, engineers, technical professionals, postdoctoral research associates, technicians, and administrative support. Material purchases include fabrication materials, vacuum hardware, vacuum pumps, pressure gauges, fast cameras, gases, data acquisition and control hardware and software, etc. needed to execute the mission. Subcontracting costs cover students. Internal services cover occasional technical editing and graphics support. Laboratory overhead is listed explicitly. No major equipment procurements were made during the performance period. 
Key objectives and achievements for the reporting period are shown in Table 2.

Table 1. Summary of Pellet Fueling Program Costs for FY 2014-2017

\begin{tabular}{|c|c|c|c|c|c|}
\hline Category & FY2014 & FY2015 & FY2016 & FY2017 & Total \\
\hline New Budget Authority & $\$ 700,000$ & $\$ 700,000$ & $\$ 700,000$ & $\$ 700,000$ & $\$ 2,800,000$ \\
\hline Labor & $\$ 437,438$ & $\$ 367,991$ & $\$ 416,258$ & $\$ 583,871$ & $\$ 1,805,558$ \\
\hline Materials & $\$ 58,987$ & $\$ 74,829$ & $\$ 62,215$ & $\$ 45,729$ & $\$ 241,760$ \\
\hline Subcontracts & $\$ 12,995$ & $\$ 8,670$ & $\$ 517$ & $\$ 31,946$ & $\$ 54,128$ \\
\hline Travel & $\$ 12,889$ & $\$ 25,052$ & $\$ 23,659$ & $\$ 23,456$ & $\$ 85,057$ \\
\hline Internal Services & $\$ 646$ & $\$ 627$ & $\$ 704$ & $\$ 1,490$ & $\$ 3,467$ \\
\hline Laboratory Overhead & $\$ 157,697$ & $\$ 144,989$ & $\$ 144,997$ & $\$ 221,221$ & $\$ 668,904$ \\
\hline Total Cost & $\$ 680,653$ & $\$ 622,159$ & $\$ 648,349$ & $\$ 907,712$ & $\$ 2,858,874 *$ \\
\hline
\end{tabular}

$*$ Note: FY2013 carryover $=\$ 284,981$, therefore total budget available $=\$ 3,084,98$.

Table 2. Key objectives and achievements for Fiscal Years 2014-2017

\begin{tabular}{|c|c|c|}
\hline Key Objective & Achievement & Fiscal Year \\
\hline $\begin{array}{l}\text { Test and optimize operation of a } \\
\text { recirculating propellant gas loop with a gas } \\
\text { gun injector, hydrogen gas compressor and } \\
\text { oil-free vacuum pump. }\end{array}$ & $\begin{array}{l}\text { A prototype propellant gas recirculation } \\
\text { loop was fabricated using tritium } \\
\text { compatible components in support of ITER. } \\
\text { The loop was operated successfully } \\
\text { for several minutes using a propellant valve } \\
\text { to mimic operation with a pellet injector. It } \\
\text { was tested for longer durations using a gas } \\
\text { flow to simulate the propellant gas to test } \\
\text { the performance of the piston pump and } \\
\text { diaphragm compressor. }\end{array}$ & \multirow[t]{2}{*}{2014} \\
\hline $\begin{array}{l}\text { Optimize the acceleration and controlled } \\
\text { shattering of cryogenic deuterium and neon } \\
\text { large pellets for disruption mitigation. } \\
\text { Incorporate capability to test ITER relevant } \\
\text { shattered pellet injection for disruption } \\
\text { mitigation on a fusion device. }\end{array}$ & $\begin{array}{l}\text { A } 16 \mathrm{~mm} \text { shattered pellet injector was } \\
\text { fabricated in the lab and operated with } \mathrm{D}_{2} \\
\text { and Ne to demonstrate large pellet } \\
\text { formation and acceleration using high } \\
\text { pressure gas. The pellets were shattered in } \\
\text { an ITER relevant bent shatter tube. }\end{array}$ & \\
\hline $\begin{array}{l}\text { Perform test of Ignitor high speed pellet } \\
\text { system with new cryocooler capability } \\
\text { utilizing remote collaboration tools. }\end{array}$ & $\begin{array}{l}\text { The new cryocooler was implemented on } \\
\text { the high-speed injector and achieved a } 9 \mathrm{~K} \\
\text { operating temperature. Remote operation } \\
\text { capability was added using Virtual Network } \\
\text { Computing and a firewall tunnel to allow } \\
\text { operation and viewing from ENEA in Italy. }\end{array}$ & \multirow[b]{2}{*}{2015} \\
\hline $\begin{array}{l}\text { Test disruption mitigation shattered pellet } \\
\text { injection on multiple fusion devices. } \\
\text { Optimize shattering geometry for use in } \\
\text { ITER shield blocks }\end{array}$ & $\begin{array}{l}\text { An shattered pellet injector (SPI) that was } \\
\text { implemented on DIII-D was modified for } \\
\text { smaller } 7 \mathrm{~mm} \text { pellets to study thermal } \\
\text { mitigation as a function of neon quantity. A } \\
\text { shatter tube design for ITER shield blocks } \\
\text { was tested in the lab and found to provide } \\
\text { adequate shattering if the angle was less } \\
\text { than } 30 \text { degrees. A } 60^{\circ} \text { angle resulted in }\end{array}$ & \\
\hline
\end{tabular}




\begin{tabular}{|c|c|c|}
\hline & $\begin{array}{l}\text { significant back flow of the shattered } \\
\text { material. }\end{array}$ & \\
\hline $\begin{array}{l}\text { Test integrated pellet formation with an } \\
\text { extruder capable of producing dual } \\
\text { adjustable pellet sizes for fueling and pellet } \\
\text { ELM pacing. }\end{array}$ & $\begin{array}{l}\text { A deuterium batch extruder was mated with } \\
\text { a dual nozzle prototype and tested in the } \\
\text { lab. Successful extrusions were created, } \\
\text { and the adjustment mechanism was verified } \\
\text { to modulate the extrusion width } \\
\text { dynamically on a } 10 \text { second time scale. The } \\
\text { force needed to actuate the adjustment } \\
\text { mechanism was measured to be } 80 \mathrm{~N}(20 \\
\text { lbf). }\end{array}$ & \multirow[t]{2}{*}{2016} \\
\hline $\begin{array}{l}\text { Test integrated pellet formation with a } \\
\text { continuous extruder capable of producing } \\
\text { dual pellet sizes for fueling and pellet ELM } \\
\text { pacing }\end{array}$ & $\begin{array}{l}\text { A continuous twin-screw extruder was } \\
\text { fabricated and tested in the lab using LHe } \\
\text { cooling. This ITER prototype extruder } \\
\text { operated with } 3 \mathrm{~mm} \text { size deuterium and was } \\
\text { operated to measure torques and heat loads } \\
\text { from the extrusion process. The dual nozzle } \\
\text { was tested off-line with a batch extruder as } \\
\text { mentioned above. }\end{array}$ & \\
\hline $\begin{array}{l}\text { Evaluate performance and effectiveness of a } \\
\text { 3-barrel ITER-like disruption mitigation } \\
\text { shattered pellet injector deployed on a fusion } \\
\text { device. }\end{array}$ & $\begin{array}{l}\text { A 3-barrel SPI system based on an ITER } \\
\text { design was developed and tested in the lab. } \\
\text { This injector was deployed on DIII-D and } \\
\text { using in initial thermal mitigation } \\
\text { experiments using simultaneous shattered } \\
\text { pellets from two different toroidal injection } \\
\text { locations for the first time. }\end{array}$ & \\
\hline $\begin{array}{l}\text { Evaluate shattering performance and } \\
\text { optimize shattering tube geometry for } \\
\text { potential use in ITER shield blocks }\end{array}$ & $\begin{array}{l}\text { The shattering of } \mathrm{D}_{2} \text { and Neon pellets was } \\
\text { studied using the JET SPI fabricated and } \\
\text { tested in the lab. The shattering fragment } \\
\text { size and duration was measured using the } \\
\text { JET prototype shatter tube and fast camera } \\
\text { to document the fragment sizes as a } \\
\text { function of species and pellet speed. Results } \\
\text { were presented at the Princeton Plasma } \\
\text { Physics Laboratory theory of disruptions } \\
\text { workshop and American Physical Society } \\
\text { (APS) } 2017 \text { and are to be published. }\end{array}$ & 2017 \\
\hline
\end{tabular}

\section{PROGRAM SUMMARY}

The pellet technology program at ORNL generated many advancements in the areas of pellet fueling and disruption mitigation science and technology during this reporting period. This section of this report provides a narrative of the work conducted within the scope of the pellet technology program from FY2014 to FY2017 and a brief overview of the science research that is enabled by this program. The pellet technology program enables collaboration with many other institutions such as ITER, Culham Center for Fusion Sciences JET and Mega-Amp Spherical Tokamak (MAST), General Atomics (DIII-D), and ENEAFrascati DEMOnstration Power Station (DEMO) by providing expertise, infrastructure and development of pellet injection science and technology; specifically, in the areas of pellet fueling, edge localized mode (ELM) pacing, and disruption mitigation (DM). This infrastructure allows ORNL pellet scientists to conduct studies on methods and hardware design that would not be possible otherwise. The remainder of this narrative discusses the progress made in the major areas noted above in the field of cryogenic pellet injection technology. 


\subsection{PELLET FUELING}

Pellet fueling is currently the most efficient way to provide core plasma density to maintain fusion burn rates. Technology developed within the scope of the pellet technology program at ORNL has enabled scientists around the world to further study fusion fueling. From FY2014 to FY2017, many R\&D tasks were conducted in the area of pellet injection. Collaborations were continued with institutions such as the University of Wisconsin (MST), Spain's Center for Energy, Environment, and Technology (TJ-II), Germany's Institute for Plasma Physics (W7-X), and Italy's ENEA-Frascati laboratory. Pellet injectors for MST and TJ-II were fabricated and commissioned in years prior to the time frame of this report, but many research tasks on them were recently published [1-3]. Barrels to allow for larger pellet sizes were fabricated for MST in late 2013. In preparation for a successful long-term collaboration with researchers at W7-X, ORNL's pellet team supplied microwave cavities to serve as in-flight pellet diagnostics for preliminary pellet experiments. A future steady-state pellet injector is currently planned for W7-X's long pulse operations. ORNL's pellet team has also continued a long-standing collaboration with researchers at ENEA-Frascati on the development on high speed pellets using two-stage light gas guns. This collaboration has been ongoing since the early 1990's. A test stand was developed in ORNL's pellet lab in support of the proposed IGNITOR machine. Although, the IGNITOR project was never realized, the pellet injector built at ORNL is still in use today [4] and is now supporting DEMO research in the European Union. This injector can be remotely operated by researchers in Italy with only oversight by ORNL staff. The Italian colleagues have remotely conducted roughly a dozen studies over the years on pellet formation and reliability using a single stage ORNL-designed propellant valve. The remote sessions are conducted to develop methods of producing the highest quality pellets to be used for during operation of the two-stage light gas gun. A new, more powerful, cryo-refrigerator was purchased by ENEA-Frascati and sent to ORNL for installation on this pellet injector enable colder operating temperatures. In June 2017, a more effective thermal shield was designed and installed to limit the radiative heat load to the freezing zones of the barrels. This addition dropped operating temperatures from $7 \mathrm{~K}$ to $5.6 \mathrm{~K}$. The decrease in pellet temperature allows for two-stage operation (pellet speeds $>2,500 \mathrm{~m} / \mathrm{s}$ ).

Beyond the collaborative efforts enabled by the pellet technology program, many technological advances have been made in ORNL's pellet lab in the area of steady-state pellet fueling. Advances in extruder systems, real-time pellet size adjustment, and minimizing propellant gas loads have been made within the time range in question. A continuous extruder system will enable fueling capabilities for long-pulse fusion devices, namely W7-X and ITER. In 2013 to 2014, the first iteration of a LHe cooled twin screw extruder (TSE) was completed and tested. A second iteration was constructed and tested in 2017. The newest iteration produced deuterium ice for $\sim 30$ minutes at a time at low throughputs. The extrusion rate measured during a successful test on July 13, 2017 was $9.9 \mathrm{~mm}^{3} / \mathrm{s}$. This iteration yielded increased thermal control due to the placement of heaters and thermal sensors in optimal locations and it was fitted with a large amount of diagnostic equipment (pressure sensors, thermal sensors, torque monitors, and flow meters). These diagnostics provided data to be used in future design iterations. In parallel with the TSE fabrication and testing, a dual nozzle and pellet size adjustment feature was designed and tested to enable real-time pellet size feedback. A cross section of this system can be seen in Figure 1. The dual nozzle splits the extrusion into two paths, each path produces a unique size extrusion. The goal of the size adjustment mechanism is to enable plasma density control systems to dictate how much material is needed for fueling at any given time and change the pellet length accordingly. The pellet size adjustor is integrated into the commonly used and well-established pellet cutter and propellant valve assembly. The diameter of a pellet is fixed by the diameter of the cutter and chambering mechanism, but the length of the pellet can be modified by adjusting the size of the extrusion. The size adjustor can also fully shut-off one side of the dual nozzle when extrusion is not needed from that side. The pellet size adjustor and dual nozzle were tested in April 2016 using a piston style batch extruder [5]. The size adjustors were 
successful in changing the size of the extrusion and shutting off the nozzle sides completely. The dual nozzle design was conceptualized to reduce the space/maintenance requirement of the pellet fueling system for ITER and other space-constrained machines.

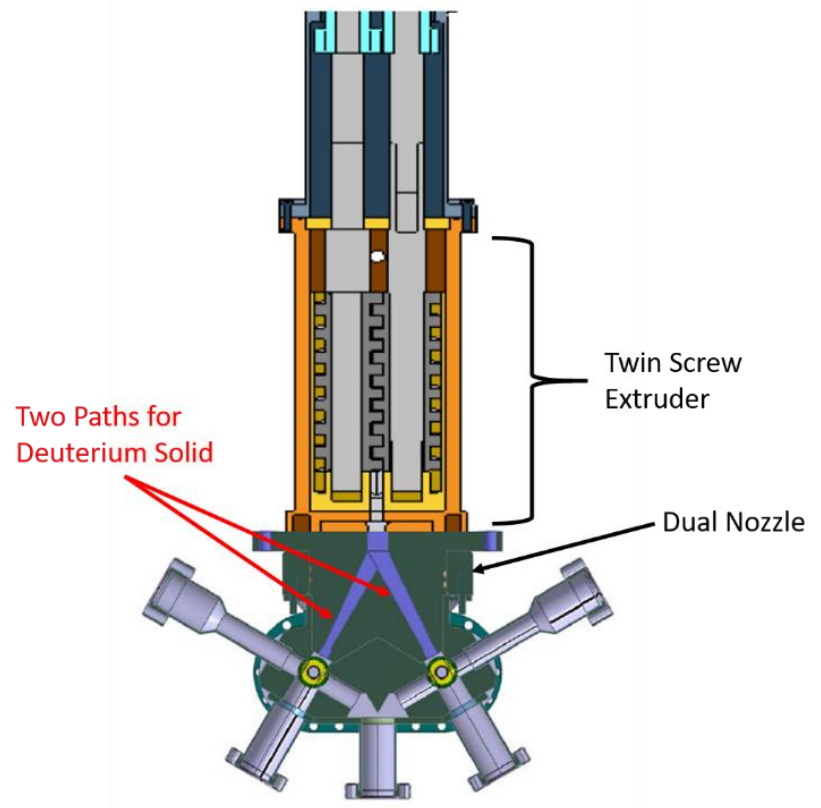

Fig. 1. A CAD model image of the dual nozzle mated to a twin-screw extruder

A comprehensive study on the propellant gas needs for fueling pellets was conducted to determine the minimal amount of gas required to achieve optimal speeds. Two pellet sizes were tested, with nominal 4.4 and $3.2 \mathrm{~mm}$ diameters comparable to pellets planned for fueling and ELM pacing in ITER. A novel scheme was used to freeze solid pellets from room temperature gas; this facilitated operation at higher temperatures (14.5 to $16.5 \mathrm{~K}$, similar to those planned for extruder operation for ITER pellet injectors) and thus a lower pellet breakaway pressures and gas load [6]. Minimizing the amount of propellant gas used to accelerate pellets drastically reduces the pumping necessary to remove it before reaching the machine downstream. Limiting the amount of propellant gas to a machine is a key parameter in pellet injection design. As stated above, this work was done with ITER sized pellets. ITER is a large force in directing the needs for pellet fueling activities. Other ITER directed activities were conducted in ORNL's pellet facilities; such as the testing of the current high field side (HFS) guide tube, the testing of a preliminary design for the pellet guide tube selector, and the design and testing of a pellet fueling recirculation loop. The HFS guide tube needed testing because of the unique geometry of the flight path. The guide tube was found to have a pellet speed limit of $\sim 300 \mathrm{~m} / \mathrm{s}$. Any pellets traveling slower than 300 $\mathrm{m} / \mathrm{s}$ survived. These results are consistent with previous studies conducted on various guide tube geometries [7,8]. Also, in support of ITER, a guide tube selector was designed and tested [9]. It was found that S-bends in the guide tubes at the exit of the selector was decreasing the survivability limit of the pellets by a large percentage. When the S-bends were removed, the survivability speed limit increased to $\sim 300 \mathrm{~m} / \mathrm{s}$. Which is consistent with the guide tube testing described above. A prototype propellant gas recirculation loop was fabricated using tritium compatible components in support of ITER. The loop was operated successfully for several minutes using a propellant valve to mimic operation with a pellet injector. It was tested for longer durations using a gas flow to simulate the propellant gas to test the 
performance of the piston pump and diaphragm compressor. The design of the ITER pellet fueling system is highly dependent on the technology developed at ORNL [10].

\subsection{EDGE LOCALIZED MODE PACING}

Technology for ELM pacing is similar to pellet fueling technology. The unique factor in ELM pacing technology is the use of slow pellets injected at different locations than fueling pellets. The slow-moving pellets ensure shallow penetration into the edge of the plasma. Various ELM pacing experiments have been carried out on DIII-D and JET to determine whether it is a viable method for reducing the amplitude, and therefore damage to the plasma facing components caused by ELMs [11].

\subsection{DISRUPTION MITIGATION}

Many tasks to advance the area of pellet injection for DM were undertaken from FY2014 to FY2017. Laboratory testing in the ORNL pellet lab led to advances in methods and technology in the area of DM. The advances made in the lab allow for more rapid implementation on fusion devices such as DIII-D and JET, and the future ITER DM system.

Laboratory testing in ORNL's pellet facilities consisted of developing the understanding of large pellet $(>10 \mathrm{~mm})$ formation in a pipe gun, forming and accelerating pellets consisting of multiple gases, temperature gradients throughout pellet material, advancing the understanding of shatter mechanics and post shatter distribution of pellet fragments, understanding of limitations on high-Z pellet breakaway, and developing and exploring alternative methods of pellet acceleration. Starting in November 2013, an ITER DM test stand in the ORNL pellet lab was used to form and accelerate large, $16.5 \mathrm{~mm}$ diameter, DM pellets. A cryo-refrigerator was used to cool the barrel to $\sim 8 \mathrm{~K}$ as it is a cheaper option than using liquid helium. The $16.5 \mathrm{~mm}$ barrel was used to explore the formation and breakaway characteristics of large pellets. This testing was dedicated to developing a method of accelerating pellets that contain high-Z materials such as neon and argon. Neon and argon have very high break away strengths at low $(<20 \mathrm{~K})$ temperatures. Conventional ORNL propellant valves are not able to supply enough pressure to break pure argon or neon pellets out of the barrel cold zone at low temperatures. Two methods were developed for the delivery of neon; a shell pellet and a mixed gas pellet. A shell pellet is formed by depositing a thin layer of deuterium on the barrel surface then slowly filling it with neon. This method utilizes the low break away strength of deuterium and allows for delivery of a maximum amount of neon. The second method of delivering neon is by freezing a mixture of neon and deuterium together, resulting in a homogenous layer of these gasses on the inner surface of the barrel. This layer has a break away strength proportional to the fraction of deuterium. A full parametric study of mixed gas pellets was conducted with respect to resulting pellet speeds, break away pressures, and mixture fractions. In parallel with the 16.5 $\mathrm{mm}$ pellet testing, a code was updated and modified to predict the temperature gradients through a large pellet. Once testing with the $16.5 \mathrm{~mm}$ pellet was concluded, a second, LHe cooled test stand was used to operate with three $24.4 \mathrm{~mm}$ diameter barrels. ITER DM designs currently contain multiple guns with 3-4 barrels each so this test stand was used to assess the possibility of multiple, large diameter barrels in one thermally coupled system. This size was chosen to explore the possibility of launching larger pellets. With larger pellets, the number of injectors required for ITER disruption mitigation can be reduced, resulting in less cost and a smaller footprint for the hardware. An attractive option consists of larger diameter and longer pellets. This $24.4 \mathrm{~mm}$ barrel was designed with a cold zone length to diameter ratio (L/D) of $\sim 3$. Mixed gas pellets, shell pellets, and pure deuterium pellets were successfully launched with this system starting in October 2014. In June 2015 a $24.4 \mathrm{~mm}$ barrel was fabricated and installed into the cryo-refrigerator cooled system for further study. This barrel had an L/D of 1.25 and was used to vigorously assess the logistics of $24.4 \mathrm{~mm}$ pellets. It was found that at $\sim 8 \mathrm{~K}$, large deuterium pellets have a warm, relatively soft center, which results in the pellets fracturing under the accelerating forces. In parallel with these tests, a single $34 \mathrm{~mm}$ barrel was installed in the LHe cooled ITER test stand. This test 
was used to show that $34 \mathrm{~mm}$ pure deuterium and shell pellets are possible if adequate cooling (LHe) is available. A code was developed to optimize the parameters of the propellant-pellet system over the summer of 2015. The code uses rarefaction physics coupled with physical system geometry to accurately predict the pellet speed when exiting the barrel. This code was benchmarked against the experiments conducted with the $16.5 \mathrm{~mm}$ and $24.4 \mathrm{~mm}$ barrels then utilized to parametrically study the current ITER DM system design with respect to valve orifice sizes and pellet sizes (response times). All work discussed above is documented in detail in [12,13].

In November of 2016, a $10 \mathrm{~mm}$ barrel was fabricated and installed on the cryo-refrigerator cooled ITER test stand to assess the formation and acceleration of pellets for the JET shattered pellet injector. The same parametric study that was conducted using $16.5 \mathrm{~mm}$ pellets was conducted with the $10 \mathrm{~mm}$ pellets, and the results were essentially the same.

In parallel with this large diameter pellet formation development work, an assessment of shatter tubes was conducted to determine angles that would ensure adequate shattering of these large pellets. A tube with a $60^{\circ}$ miter bend was shown to be too great of an angle for large pellets. The pellet shattered, but also resulted in significant back flow of the shattered material, which is not ideal for use on a fusion device. In May of 2017, the second DIII-D shattered pellet injector (SPI2) shatter tube was tested using an $8.5 \mathrm{~mm}$ pellet. This barrel was used to test a mechanical punch device intended for the acceleration of pure argon pellets at high temperatures $(>55 \mathrm{~K})$. Pure argon and neon pellets were successfully launched with the mechanical punch, and subsequently shattered by the $20^{\circ}$ bend in the shatter tube. High speed video of this shatter spray was analyzed to determine the particle size distribution and time evolution of the shatter plume. This data was compared to pellet shatter theory with the goal of providing experimental data to computational physicists to support development of more accurate simulation of shattered pellet injection. This work is still ongoing as more experimental shatter data is needed.

Basic research on how to predict mechanical punch reliability for argon and neon pellets is currently under development. A significant effort has gone into the design and modeling of these devices for "dry fire" and pellet impact scenarios. Punches have been designed with pressure and velocity diagnostics to help validate the modeling efforts. This work was initiated to support the JET shattered pellet system and future ITER DM systems.

In addition, an electrothermal (ET) plasma source was used to accelerate surrogate, polycarbonate, pellets as an alternative method of pellet injection utilizing a system set up under an LDRD project to investigate the use of an ET source as a test bed for high heat flux Plasma Material Interaction studies. An ET plasma source is a pulsed plasma source that forms a high-momentum unidirectional jet of plasma. This momentum can be imparted onto a projectile. A study was conducted comparing the energy efficiencies of the ET source to the conventional ORNL gas guns [14]. The ET source was able to accelerate polycarbonate pellets to speeds $>700 \mathrm{~m} / \mathrm{s}$. The erosion of source liner material that follows the pellet was found to be a deterrent to using this type of acceleration system.

Developing this technology in laboratory tests allows for a deeper understanding of the science in question, which is then translated to fusion devices around the world. A good example is work conducted by ORNL's pellet scientists and engineers on the design of a massive gas injection system for use on DIII-D. In 2014, it was found that Massive Gas Injectino (MGI) results in non-uniform radiation during a disruption event [15]. In 2016 the first results from SPI using neon on DIII-D was presented [16]. This work was conducted with an upgraded injector that was refitted with a larger barrel and the ability to include neon. A comparison to MGI showed that SPI, using similar quantities of neon, provided a faster and stronger density perturbation and neon assimilation. This resulted in a lower conducted energy to the divertor and a more rapid onset of thermal quench (TQ). Radiated power data analysis shows that this was probably due to the much deeper penetration of the neon in the plasma inducing higher core radiation than observed during 
MGI. This experiment also revealed that the magnetohydrodynamic activity during an SPI shutdown (especially during the TQ) is quite different compared to MGI. This favorable TQ energy dissipation was obtained while keeping the current quench duration within acceptable limits when scaled to ITER. The positive results described in [16] enabled the design of a second SPI system on DIII-D. The laboratory testing discussed above concerning the three-barrel, LHe cooled, SPI was used to design SPI2 for DIII-D [17]. This injector was commissioned in ORNL's pellet lab in July 2016 and installed on the machine shortly after (mid-late August 2016). SPI2 has been involved in various experiments over the past year including a comparison of mitigation between SPI1 and SPI2, testing an ITER like DM scenario where the shatter plume is non-core directed, and testing scenarios related to staggered pellet-to-plasma arrival times. These experiments were conducted throughout FY2017 and the campaigns are ongoing. To gain further understanding of DM techniques, a SPI was designed for use on JET. This injector was assembled and commissioned in the ORNL pellet lab in the Fall of 2017. It is currently being installed on JET and commissioning is expected to occur around the end of August 2018. Results on JET will provide valuable information for future, large, high energy density tokamaks. All research and design activities enabled by the pellet technology program at ORNL add to the knowledge base required to design a future fusion power plant, with ITER being an intermediate step. Disruption mitigation on ITER is essential owing to the intense heat flux, large electromagnetic forces, and possible creation of runaway electrons during a disruption event. The preliminary design parameters for the ITER DM system have been identified by ORNL and USITER [18].

\subsection{REFERENCES (CITED IN PROGRAM NARRATIVE}

1. B.E. Chapman, K.J. Anderson, W. Capecchi, D.J. Den Hartog, S.T. Limbach, L.A. Morton, S.P. Oliva, E. Parke, J.S. Sarff, W.C. Young, D.L. Bower, W.X. Ding, J.R. Duff, L. Lin, and S.K. Combs, "Probing the limits on beta and density in the RFP," Bull. Am. Phys. Soc. 59(15), Abstract PP8.00016, p. 252 (2014). [Presented at the 56 ${ }^{\text {th }}$ Annual Meeting of the APS Division of Plasma Physics, New Orleans, Louisiana, 27-31 October 2014 (American Physical Society)]

2. N. Panadero, K. J. McCarthy, S. K. Combs, C. Foust, R. García, J. Hernández Sánchez, F. Martín, M. Navarro, "First hydrogen pellet injections in the TJ-II stellarator," Proceedings XXXV Bienal de la RSEF y XXV Encuentro Ibérico para la Enseñanza de la Física, Gijón, Spain (July 2015) pp. 249-250.

3. K.J. McCarthy, N. Panadero, J.L. Velasco, S.K. Combs, J.B.O. Caughman, J.M. Fontdecaba, C. Foust, R. Garcia, J. Hernández Sánchez, M. Navarro, I. Pastor, A. Soleto and the TJ-II Team, "Plasma fueling with cryogenic pellets in the stellarator TJ-II," Nucl. Fusion 57 (2017) 056039.

4. F. Bombarda, A. Frattolillo, S. Migliori, F. Iannone, S. Podda, G. D'Elia, L.R. Baylor, and S.K. Combs, "State of the art and perspective of high-speed pellet injection technology," Fusion Engineering and Design 124 (2017) 797-800.

5. S. K. Combs, C. R. Foust, and A. L. Qualls, “ Extruder System for High-Throughput/SteadyState Hydrogen Ice Supply and Application for Pellet Fueling of Reactor-Scale Fusion Experiments,” Rev. Sci. Instrum. 69 (11), 4012-4013 (November 1998).

6. S.K. Combs, L.R. Baylor, C.R. Foust, A. Frattolillo, M.S. Lyttle, S.J. Meitner, and S. Migliori, "Experimental Study of the Propellant Gas Load Required for Pellet Injection with ITER-Relevant Operating Parameters," Fusion Science and Technology 68 (September 2015) 
319-325. [Presented at $21^{\text {th }}$ Topical Meeting on the Technology of Fusion Energy (TOFE-2014), Anaheim, CA, 9-13 November 2014]

7. S. K. Combs, L. R. Baylor, C. R. Foust, M. J. Gouge, T.C. Jernigan, and S. L. Milora, "Experimental Study of Curved Guide Tubes for Pellet Injection," in Proc. 1997 IEEE/NPSS 17th Symposium Fusion Engineering, San Diego, California, October 6-10, 1997, Vol.2 (Institue of Electrical and Electronics Engineers, IEEE Cat. No. 97CB36131, Piscataway, NJ, 1998) pp. 11021105 .

8. S. K. Combs, L. R. Baylor, J. B. O. Caughman, D. T. Fehling, C. R. Foust, T. C. Jernigan, S. Maruyama, J. M. McGill, D. A. Rasmussen, J. A. Ridenour, and M. Watson, "Pellet delivery and survivability through curved guide tubes for fusion fueling and its implications for ITER, Fusion Engineering and Design 75-79, 691-696 (November 2005). [Proceedings of $23^{\text {rd }}$ Symposium on Fusion Technology, Venice, Italy, September 20-24, 2004].

9. S.J. Meitner, L.R. Baylor, S.K. Combs, C.R. Foust, T.T. Ha, K.G. Loganb, T.P. Bjorholm, M.S. Lyttle, S. Migliori, and A. Frattolillo, "Selectable Flight Tube Design Developments for ITER Fueling, ELM Pacing, and Impurity Pellets, Proc. $26^{\text {th }}$ Symposium on Fusion Engineering (SOFE), May 31-June 4, 2015, Austin, TX (Paper SP10-12, DVD, IEEE Catalog Number: CFP15SOFDVD, ISBN: 978-1-4799-8263-9).

10. L. R. Baylor, S. K. Combs, R. C. Duckworth, M. S. Lyttle, S. J. Meitner, D. A. Rasmussen, and S. Maruyama, "Pellet Injection Technology and Applications on ITER," IEEE Transactions on Plasma Science, Vol. 44/No. 9 (September 2016) 1489-1495.

11. L.R. Baylor, P.T. Lang, S.L. Allen, S.K. Combs, N. Commaux, T.E. Evans, M.E. Fenstermacher, G. Huijsmans, T.C. Jernigan, C.J. Lasnier, A.W. Leonard, A. Loarte, R. Maingi, S. Maruyama, S.J. Meitner, R.A. Moyer, and T.H. Osborne, "ELM mitigation with pellet triggering and implications for PFCs and plasma performance in ITER,” Journal of Nuclear Materials 463 (2015) 104-108.

12. S. K. Combs, S. J. Meitner, T. E. Gebhart, L. R. Baylor, J. B. O. Caughman, D. T. Fehling, C. R. Foust, T. Ha, M. S. Lyttle, J. T. Fisher, and T. R. Younkin, "Solidification and Acceleration of Large Cryogenic Pellets Relevant for Plasma Disruption Mitigation," IEEE Transactions on Plasma Science, Vol. 44/No. 9 (September 2016) 1506-1513.

13. S.K. Combs, J.R. Reed, M.S. Lyttle, L.R. Baylor, J.R. Carmichael, T.E. Gebhart, S.J. Meitner, and D.A. Rasmussen, "Gas Gun Model and Comparison to Experimental Performance of Pipe Guns Operating with Light Propellant Gases and Large Cryogenic Pellets," Fusion Science and Technology 72 (2017) 404-415.

14. T.E. Gebhart, S.K. Combs, and L.R. Baylor, "Comparison of an Electrothermal Plasma Source to a Light Gas Gun for Launching Large Cryogenic Pellets for Tokamak Disruption Mitigation," Fusion Science and Technology 73 (2017) 25-33.

15. N. Commaux, L. R. Baylor, T.C. Jernigan, E.M. Hollmann, D.A. Humphreys, J.C. Wesley, V.A. Izzo, N.W. Eidietis, C.J. Lasnier, R.A. Moyer, P.B. Parks, C.R. Foust, S. Combs, and S.J Meitner, "Radiation asymmetries during disruptions on DIII-D caused by massive gas injection," Physics of Plasmas 21-10 (2014) 102510-1.

16. N. Commaux, D. Shiraki, L.R. Baylor, E.M. Hollmann, N.W. Eidietis, C.J. Lasnier, R.A. Moyer, T.C. Jernigan, S.J. Meitner, S.K. Combs, and C.R. Foust, "First demonstration of rapid shutdown 
using neon shattered pellet injection for thermal quench mitigation on DIII-D," Nucl. Fusion 56 (2016) 046007 (7 pp).

17. S. Meitner, L.R. Baylor, N. Commaux, D. Shiraki, S. Combs, T. Bjorholm, T. Ha, and W. McGinnis, "Design and Commissioning of a Three-Barrel Shattered Pellet Injector for DIII-D Disruption Mitigation Studies," Fusion Science and Technology 72 (2017) 318-323.

18. L.R. Baylor, C.C. Barbier, J.R. Carmichael, S.K. Combs, M.N. Ericson, N.D. Bull Ezell, P.W. Fisher, M.S. Lyttle, S.J. Meitner, D.A. Rasmussen, S.F. Smith, J.B. Wilgen, S. Maruyama, and G. Kiss, "Disruption Mitigation System Developments and Design for ITER," Fusion Science and Technology 68 (September 2015) 211-215. [Presented at $21^{\text {th }}$ Topical Meeting on the Technology of Fusion Energy (TOFE-2014), Anaheim, CA, 9-13 November 2014].

\section{PRODUCTS}

The products of the program include conference papers and presentations, journal articles, test articles, and test stands developed according to the demands at hand. As the testing hardware and test articles are described in the various technical papers, only journal articles, proceedings, laboratory reports and abstracts/presentations are listed here.

\subsection{JOURNAL ARTICLES}

1. S. K. Combs and L. R. Baylor, "Pellet Injector Technology - Brief History and Key Developments in the Last 25 Years," Fusion Science and Technology, Vol. 493, Issue 4, pp. 493-518, 2018.

2. T.E. Gebhart, S.K. Combs and L.R. Baylor, "Comparison of an Electrothermal Plasma Source to a Light Gas Gun for Launching Large Cryogenic Pellets for Tokamak Disruption Mitigation," Fusion Science and Technology 73 (2017) 25-33.

3. F. Bombarda, A. Frattolillo, S. Migliori, F. Iannone, S. Podda, G. D'Elia, L.R. Baylor and S.K. Combs, "State of the art and perspective of high-speed pellet injection technology," Fusion Engineering and Design 124 (2017) 797-800.

4. M.S. Lyttle, L.R. Baylor, R.E. Battle, S.J. Meitner, D.A. Rasmussen and J.M. Shoulders, "Tritium Challenges and Plans for ITER Pellet Fueling and Disruption Mitigation Systems," Fusion Science and Technology 71 (3), 251-255 (2017).

5. S.K. Combs, J.R. Reed, M.S. Lyttle, L.R. Baylor, J.R. Carmichael, T.E. Gebhart, S.J. Meitner, and D.A. Rasmussen, "Gas Gun Model and Comparison to Experimental Performance of Pipe Guns Operating with Light Propellant Gases and Large Cryogenic Pellets," Fusion Science and Technology 72 (2017) 404-415.

6. S. Meitner, L.R. Baylor, N. Commaux, D. Shiraki, S. Combs, T. Bjorholm, T. Ha, and W. McGinnis, "Design and Commissioning of a Three-Barrel Shattered Pellet Injector for DIII-D Disruption Mitigation Studies," Fusion Science and Technology 72 (2017) 318-323.

7. L. Carbajal, D. del-Castillo-Negrete, D. Spong, S. Seal and L.R. Baylor, "Space dependent, full orbit effects on runaway electron dynamics in tokamak plasmas," Physics of Plasmas 24 (4), 042512 (2017). 
8. L.R. Baylor and S.J. Meitner, "Tritium Aspects of Fueling and Exhaust Pumping in Magnetic Fusion Energy," $11^{\text {th }}$ International Conference on Tritium Science and Technology (Tritium 2016), Charleston, SC, April 17-22, 2016. Fusion Science and Technology, Vol. 71, pp. 581-587, 2017.

9. K.J. McCarthy, N. Panadero, J.L. Velasco, S.K. Combs, J.B.O. Caughman, J.M. Fontdecaba, C. Foust, R. Garcia, J. Hernández Sánchez, M. Navarro, I. Pastor, A. Soleto and the TJ-II Team, "Plasma fueling with cryogenic pellets in the stellarator TJ-II," Nucl. Fusion 57 (2017) 056039.

10. S.K. Combs, S.J. Meitner, T.E. Gebhart, L.R. Baylor, J.B.O. Caughman, D.T. Fehling, C.R. Foust, T. Ha, M.S. Lyttle, J.T. Fisher, and T.R. Younkin, "Solidification and Acceleration of Large Cryogenic Pellets Relevant for Plasma Disruption Mitigation," IEEE Transactions on Plasma Science, Vol. 44/No. 9 (September 2016) 1506-1513.

11. L.R. Baylor, S.K. Combs, R.C. Duckworth, M.S. Lyttle, S.J. Meitner, D.A. Rasmussen and S. Maruyama, "Pellet Injection Technology and Applications on ITER," IEEE Transactions on Plasma Science, Vol. 44/No. 9 (September 2016) 1489-1495.

12. N. Tamura, K J. McCarthy, H. Hayashi, S.K. Combs, C. Foust, R. García, N. Panadero, E. Pawelec, J. Hernández Sánchez, M. Navarro, and A. Soleto, "Tracer-encapsulated solid pellet (TESPEL) injection system for the TJ-II stellarator," Rev. Sci. Instrum. 87 (2016) 11 D619.

13. D. Shiraki, N. Commaux, L. R. Baylor, N.W. Eidietis, E. M. Hollman, C. J. Lasnier, R. A. Moyer, "Thermal Quench Mitigation and Current Quench Control by Injection of Mixed Species Shattered Pellets in DIII-D," Phys. of Plasmas, Vol. 23 (6), 062516 (2016).

14. A. Bortolon, R. Maingi, D.K. Mansfield, A. Nagy, A. L. Roquemore, L.R. Baylor, et al., "High Frequency Pacing of Edge Localized Modes by Injection of Lithium Granules in DIII-D H-mode Discharges," Nuclear Fusion, Vol. 56 (2016).

15. L. R. Baylor, S. K. Combs, R. C. Duckworth, M. S. Lyttle, S. J. Meitner, D.A. Rasmussen, S. Maruyama, "Pellet Injection Technology and its Applications on ITER," IEEE Transactions on Plasma Science, Vol. 44, pp. 1489-1495 (2016).

16. N. Commaux, D. Shiraki, L.R. Baylor, E.M. Hollmann, N.W. Eidietis, C.J. Lasnier, R.A. Moyer, T. C. Jernigan, S. J. Meitner, S. K. Combs and C. R. Foust, "First demonstration of rapid shutdown using neon shattered pellet injection for thermal quench mitigation on DIII-D," Nucl. Fusion 56 (2016) 046007 (7 pp).

17. L.R. Baylor, C.C. Barbier, J.R. Carmichael, S.K. Combs, M.N. Ericson, N.D. Bull Ezell, P.W. Fisher, M.S. Lyttle, S.J. Meitner, et al., "Disruption Mitigation System Developments and Design for ITER," Fusion Science and Technology 68 (September 2015) 211-215.

18. S.K. Combs, L.R. Baylor, C.R. Foust, A. Frattolillo, M.S. Lyttle, S.J. Meitner and S. Migliori, "Experimental Study of the Propellant Gas Load Required for Pellet Injection with ITER-Relevant Operating Parameters," Fusion Science and Technology 68 (Sept. 2015) 319-325.

19. D. Shiraki, N. Commaux, L. R. Baylor, N. W. Eidietis, E. M. Hollmann, V. A. Izzo, R.A. Moyer, C. Paz-Soldan, "Characterization of MHD Activity and its Influence on Radiation Asymmetries During Massive Gas Injection in DIII-D," Nuclear Fusion, Vol. 55 (2015). 
20. S.J. Meitner, L.R. Baylor, et al., "Pellet Selector and Flight Tube Trajectory Developments for ITER Fueling, ELM Pacing, and Impurity Pellets," IEEE, Symp. on Fusion Eng. (SOFE) (2015).

21. L.R. Baylor, P.T. Lang, S.L. Allen, S.K. Combs, N. Commaux, T.E. Evans, M.E. Fenstermacher, G. Huijsmans, T.C. Jernigan, C.J. Lasnier, A.W. Leonard, A. Loarte, R. Maingi, S. Maruyama and S.J. Meitner, et al., "ELM mitigation with pellet triggering and implications for PFCs and plasma performance in ITER," Journal of Nuclear Materials 463 (2015) 104-108.

22. S. Futatani, G. Huijsmans, A. Loarte, L. R. Baylor, et al., "Non-Linear MHD Modelling of ELM Triggering by Pellet Injection in DIII-D and Implications for ITER," Nuc. Fusion, Vol. 54 (2014).

23. S.J. Meitner, L.R. Baylor, et al., "Cryogenic Pellet Production Developments for Long-Pulse Plasma Operation," Advances in Cryogenics Engineering, Conf., Anchorage, Alaska, AIP Conf. Proc. 1573 (2014).

24. N. Commaux, L. R. Baylor, T.C. Jernigan, E.M. Hollmann, D.A. Humphreys, J.C. Wesley, V.A. Izzo, N.W. Eidietis, C.J. Lasnier, R.A. Moyer, P.B. Parks, C.R. Foust, S. Combs, and S.J. Meitner, "Radiation asymmetries during disruptions on DIII-D caused by massive gas injection," Physics of Plasmas 21 (2014) 102510-1.

25. A. Loarte, L.R. Baylor, et al., "Progress on the application of ELM control schemes to ITER scenarios from the non-active phase to DT operation," Nucl. Fusion 54033007 (2014).

26. Zhehui Wang, S.K. Combs, L.R. Baylor, C.R. Foust, M.S. Lyttle, S.J. Meitner and D.A. Rasmussen, "Fast imaging of intact and shattered cryogenic neon pellets," Rev. Sci. Instrum. 85 (2014) 11E805.

27. S.K. Combs, C.R. Foust, J.M. McGill, J.B.O. Caughman, K.J. McCarthy, L.R. Baylor, M. Chamorro, D.T. Fehling, R. Garcia, J.H. Harris, J. Hernández Sánchez, C. Hidalgo, S.J. Meitner, D.A. Rasmussen, and R. Unamuno, "Results from Laboratory Testing of a New FourBarrel Pellet Injector for the TJ-II Stellarator," Fusion Science and Technology 64 (September 2013) 513-520.

28. L.R. Baylor, N. Commaux, T.C. Jernigan, S.J. Meitner and S.K. Combs, et al., "Reduction of edge localized mode intensity on DIII-D by on-demand triggering with high frequency pellet injection and implications for ITER," Physics of Plasmas 20 (2013) 082413 (8 pp).

29. G.M Olynyk, R.S. Granetz, M.L. Reinke, D.G. Whyte, T. Golfinopoulus, J.W. Hughes, J.R. Walk, V.A. Izzo, S.K. Combs and S.L. Milora, et al., "Rapid shutdown experiments with one and two gas jets on Alcator C-Mod," Nucl. Fusion 53 (2013) 092001 (6 pp).

30. X. Litaudon, JET-EFDA Contributors, et al., "Modeling of Hybrid Scenario: from Present-Day Experiments Towards ITER," X. Litaudon, IAEA, Vienna, Nuclear Fusion, Vol. 53 (2013).

31. P.T. Lang, L.R. Baylor, et al., "ELM control strategies and tools: status and potential for ITER," IEAA Vienna, Nucl. Fusion 53043004 (2013).

32. L.R. Baylor, N. Commasux, T.C. Jerrnigan. N.H. Brooks, S. K. Combs, T.E. Evans, M.E. Fenstermacher, R.C. Isler, C.J. Lasnier and S.J. Meitner, et al., "Reduction of Edge-Localized Mode Intensity Using High-Repetition-Rate Pellet Injection in H-Mode Plasmas," Physical Review Letters 110, 245001 (2013). 


\subsection{PROCEEDINGS}

1. L. R. Baylor, S. J. Meitner, and T. E Gebhart, Shattered Pellet Injection for Disruption Mitigation in KSTAR, KSTAR Conference, Muju, South Korea, February 2018.

2. S.K. Combs, S.J. Meitner, T.E. Gebhart, L.R. Baylor, J.B.O. Caughman, D.T. Fehling, C.R. Foust, T. Ha, M.S. Lyttle, J.T. Fisher, and T.R. Younkin, "Recent Developments in Support of the Shattered Pellet Technique for Disruption Mitigation," Proc. $26^{\text {th }}$ Symposium on Fusion Engineering (SOFE), May 31-June 4, 2015, Austin, TX (Paper SO18-6/invited talk), DVD, IEEE Catalog Number: CFP15SOF-DVD, ISBN: 978-1-4799-8263-9).

3. L.R. Baylor, S.K. Combs, R.C. Duckworth, M.S. Lyttle, S.J. Meitner, D.A. Rasmussen, and S. Maruyama, "Pellet Injection Technology and Applications on ITER," Proc. $26^{\text {th }}$ Symposium on Fusion Engineering (SOFE), May 31-June 4, 2015, Austin, TX (Paper SO18-3/invited talk, DVD, IEEE Catalog Number: CFP15SOF-DVD, ISBN: 978-1-4799-8263-9).

4. M.S. Lyttle, L.R. Baylor, J.R. Carmichael, S.K. Combs, M.N. Ericson, N.D. Bull-Ezell, P.W. Fisher and S.J. Meitner, et al., "Fast Acting Eddy Current Driven Valve for Massive Gas Injection on ITER," Proc. $26^{\text {th }}$ Symposium on Fusion Engineering (SOFE), May 31-June 4, 2015, Austin, TX (Paper SP10-13, DVD, IEEE Catalog Number: CFP15SOF-DVD, ISBN: 978-1-4799-8263-9).

5. S.J. Meitner, L.R. Baylor, S.K. Combs, C.R. Foust, T.T. Ha, K.G. Loganb, T.P. Bjorholm, M.S. Lyttle, S. Migliori, and A. Frattolillo, "Selectable Flight Tube Design Developments for ITER Fueling, ELM Pacing, and Impurity Pellets," Proc. $26^{\text {th }}$ Symposium on Fusion Engineering (SOFE), May 31-June 4, 2015, Austin, TX.

6. N. Panadero, K. J. McCarthy, S. K. Combs, C. Foust, R. García, J. Hernández Sánchez, F. Martín, M. Navarro, "First hydrogen pellet injections in the TJ-II stellarator," Proceedings XXXV Bienal de la RSEF y XXV Encuentro Ibérico para la Enseñanza de la Física, Gijón, Spain (July 2015) pp. 249-250.

7. S. Maruyama, G. Kiss, F. Villers, Y. Yang, M. Lehnen, L. R. Baylor, et al., "ITER Disruption Mitigation Technologies and Beyond," IEEE 26 ${ }^{\text {th }}$ Symp. on Fusion Eng. (SOFE) (2015).

8. K. J. McCarthy, N. Panadero, I. Arapoglou, S. Combs, J. B. O. Caughman, E. de la Cal, C. Foust, R. García, J. Hérnandez-Sánchez, F. Martín, M. Navarro, M. A. Ochando, I. Pastor, M. C. Rodríguez and J. L. Velasco, "The Pellet Injector and its Associated Diagnostics for Performing Plasma Studies in the TJ-II Stellarator," Proceedings of Science (1st EPS Conference on Plasma Diagnostics - ECPD2015) 134, Frascati, Italy (14-17 April 2015).

9. L.R. Baylor, C. C. Barbier, J. R. Carmichael, S.K. Combs, M. N. Ericson, N.D. Bull Ezell, P.W. Fisher, M.S. Lyttle and S.J. Meitner, et al., "Disruption Mitigation System Developments and Design for ITER," 25th IAEA Fusion Energy Conference, Saint Petersburg, Russian Federation, 13-18 October 2014, Contributed paper FIP/2-1.

10. K.J. McCarthy, S. Combs, L. Baylor, J. Caughman, D. Fehling, C. Foust, R. García, J. Hérnandez Sánchez, F. Martín, J. McGill, M. Navarro, N. Panadero. and D. Rasmussen, "A Hydrogen Pellet Injection System and Associated Ha Light Diagnostics for Performing Plasma Studies and Fuelling in the TJ-II Stellarator," Proceedings XXXIV Bienal de la RSEF y el XXIII Encuentro Ibérico para la Enseñanza de la Física, Valencia, Spain (July 2013). 
11. S.J. Meitner, L.R. Baylor, S.K. Combs, D.T. Fehling, J.M. McGill, R.C. Duckworth, W.D. McGinnis, and D.A. Rasmussen, "Cryogenic Pellet Production Developments for LongPulse Plasma Operation," AIP Conference Proceedings - Advances in Cryogenic Engineering, Vol. 1573, 59B (2013) 1475. [Presented at the 2013 Cryogenic Engineering Conference and International Cryogenic Materials Conference (CEC/ICMC 2013), Anchorage, Alaska, June 17 $21,2013]$.

12. G. Kiss, S. Maruyama, S. Putvinski, M. Sugihara, L. R. Baylor, et al., "ITER Disruption Mitigation System Development and Port Plug Integration," IEEE $25^{\text {th }}$ Symp. on Fusion Engineering (SOFE) (2013).

13. R. C. Duckworth, L. R. Baylor, et al., "Single-Phase, Helium Gas Transfer Lines for Cryogenic Heat Transfer Applications," Cryogenic Engineering Conference \& International Cryogenic Materials Conference, Anchorage, Alaska (2013).

\subsection{ABSTRACTS AND PRESENTATIONS}

1. S.K. Combs, "Brief History and Status of Cryogenic Pellets in Fusion Energy Research," presented at $27^{\text {th }}$ Symposium on Fusion Engineering, Shanghai, China, 4-8 June 2017. [Invited talk].

2. L.R. Baylor, S.J. Meitner, S.K. Combs, T.E. Gebhart, M. Lyttle and D.A. Rasmussen, "Developments and Challenges in Shattered Pellet Technology and Implementation on JET and ITER," ITPA MHD Meeting, Barcelona, Spain, October 10, 2017.

3. L.R. Baylor, S.J. Meitner, S.K. Combs, T.E. Gebhart, D.A. Rasmussen and M. Lyttle, "Developments in Shattered Pellet Technology and Implementation on JET and ITER," Theory and Simulation of Disruptions Workshop, Princeton Plasma Physics Laboratory, July 17, 2017.

4. R.D. Duckworth, L.R. Baylor, S.J. Meitner, J. Saunders, M. Howell, B. Degraff and P. Lukens, Integration of Prototype Cryoviscous Compressor into SNS Cryogenic Test Facility for Demonstration Performance Characterization," 2017 Cryogenic Engineering Conference/International Cryogenic Materials Conference, Madision, WI, July 9-13, 2017.

5. S.J. Meitner, "Installation of $2^{\text {nd }}$ Shattered Pellet Injector for Disruption Mitigation on DIII-D," Oak Ridge National Laboratory, May 3, 2017.

6. D.A. Rasmussen, M.S. Lyttle, L.R. Baylor, J.R. Carmichael, J.B.O. Caughman, S.K. Combs, N.M. Ericson, N.D. Bull-Ezell, D.T. Fehling, P.W. Fisher, C.R. Foust, T. Ha, S.J. Meitner, A. Nycz, J.M. Shoulders, S.F. Smith, R.J. Warmack, J.D. Colburn, T.E. Gebhart, et al., "ITER Disruption Mitigation System Design," Bull. Am. Phys. Soc. 60(19), Abstract PP12.00113. [Presented at the 57th Annual Meeting of the APS Division of Plasma Physics, Savannah, Georgia, 16-20 Nov. 2015 (American Physical Society)].

7. S.K. Combs, L.R. Baylor, C.R. Foust, A. Frattolillo, M.S. Lyttle, SJ. Meitner, and S. Migliori, "Experimental Study of the Propellant Gas Load Required for Pellet Injection with ITERRelevant Operating Parameters," presented at $21^{\text {th }}$ Topical Meeting on the Technology of Fusion Energy, Anaheim, CA, 9-13 November 2014 [published in special issue of journal: Fusion Science and Technology 68 (September 2015) 319-325)]. 
8. L.R. Baylor, C.C. Barbier, J.R. Carmichael, S.K. Combs, M.N. Ericson, N.D. Bull Ezell, P.W. Fisher, M.S. Lyttle, S.J. Meitner, et al., "Disruption Mitigation System Developments and Design for ITER," presented at $21^{\text {th }}$ Topical Meeting on the Technology of Fusion Energy, Anaheim, CA, 9-13 November 2014 [published in special issue of journal: Fusion Science and Technology 68 (September 2015) 211-215)].

9. N. Commaux, D. Shiraki, L. R. Baylor, S.J. Meitner and S.K. Combs, et al., "Influence of DIII-D Experiments on the Design of the ITER Shattered Pellet Injection System," Bull. Am. Phys. Soc. 59(15), Abstract UO3.00015, p. 328 (2014). [56 ${ }^{\text {th }}$ Annual Mtg. of the APS Division of Plasma Physics, New Orleans, Louisiana, 27-31 October 2013 (Am. Physical Society)].

10. K.J Caspary, B.E. Chapman, J.K. Anderson, S.T. Limbach, S.P. Oliva, J.S. Sarff, J. Waksman, S.K. Combs, and C.R. Foust, "Probing RFP Density Limits and the Interaction of Pellet Fueling and NBI Heating on MST," Bull. Am. Phys. Soc. 58(16), Abstract CP8.00091 (2013). [Presented at the $55^{\text {th }}$ Annual Meeting of the APS Division of Plasma Physics, Denver, Colorado, 11-15 November 2013 (American Physical Society)].

11. S.K. Combs, "A Review of Pellet Injector Technology and Applications," presented at $25^{\text {th }}$ Symposium on Fusion Engineering, San Francisco, CA, 10-14 June 2013. [Invited talk].

\section{KEY PERSONNEL}

Key research and engineering staff members for this program are listed in Table 3 and biographical information is provided following Table 3.

Table 3. Key personnel, job titles, and program roles

\begin{tabular}{|l|l|l|}
\hline Name & Job Title & Program Role \\
\hline Larry R.Baylor & Distinguished R\&D Staff & $\begin{array}{l}\text { Principle Investigator, } \\
\text { Instrumentation and } \\
\text { Controls, and Testing }\end{array}$ \\
\hline Stephen K. Combs & Distinguished R\&D Staff & $\begin{array}{l}\text { Engineering, Assembly, } \\
\text { and Testing }\end{array}$ \\
\hline Steve J. Meitner & R\&D Staff & $\begin{array}{l}\text { Design, Engineering, } \\
\text { Analysis, Fabrication and } \\
\text { Testing }\end{array}$ \\
\hline Trey E. Gebhart & Post Doc & $\begin{array}{l}\text { Analysis, Assembly, and } \\
\text { Testing }\end{array}$ \\
\hline Charles R. Foust & $\begin{array}{l}\text { Technical Associate Staff } \\
\text { Member }\end{array}$ & $\begin{array}{l}\text { Engineering and } \\
\text { Assembly }\end{array}$ \\
\hline Tam Ha & Staff Technician & Assembly and Testing \\
\hline Gary L. Bell & Manager 3 & Project Management \\
\hline
\end{tabular}


Dr. Larry R. Baylor - Dr. Baylor is a distinguished staff scientist in the Fusion and Materials for Nuclear Systems Division of the Oak Ridge National Laboratory (ORNL), involved with plasma fueling and transport studies in the field of magnetic fusion energy and in the development of nanotechnology. He is the author or coauthor of over 140 papers published in journals and 75 in conference proceedings. He is an inventor on 5 patents that have been granted to ORNL. Since 1989 he has served as a research staff member in ORNL's Fusion Energy Division. Before that time, he was an instrumentation engineer supporting magnetic fusion experiments at ORNL. His engineering experience consists of cryogenic instrumentation, plasma diagnostics, computer data acquisition, and programmable logic controls. He was responsible for the data acquisition system for the \$100M International Fusion Superconducting Magnet Facility in the 1980s.

Dr. Baylor has been a primary contributor to the design and participated in the experimental program for fueling systems on several major magnetic fusion devices (TFTR, JET, Tore Supra, DIII-D, W7-AS, and the Large Helical Device). He spent two years at the JET Joint Undertaking in the United Kingdom where he maintained and operated an ORNL pellet injector and did his Ph.D. research on plasma particle transport on JET. He played a critical role in the experiments on JET that achieved the pellet enhanced performance mode, which led to the fundamental understanding of improved confinement in reverse shear tokamak plasmas. He played a major role in the design of the tritium pellet injector for TFTR, the JET multi-pellet injector, and DIII-D pellet injector. He is currently the principle investigator on pellet fueling at DIII-D, where inner wall pellet fueling, ELM pacing, and disruption mitigation techniques have been developed and investigated for use on ITER

Dr. Baylor participated in the fueling system research and development activities for ITER and is currently the technical lead for the fueling, pumping, and disruption mitigation system design activities for the US ITER project. He has participated in organizing conferences and has been on the program committee for the APS Division of Plasma Physics and involved in working groups of the International Tokamak Physics Activity (ITPA) since 2002. He is presently on the council of the U.S. Burning Plasma Organization.

Stephen K. Combs - Mr. Combs retired from ORNL in December 2017 after a 45-year career. He retired as a distinguished staff scientist from the Fusion and Materials for Nuclear Systems Division. Steve started his career at ORNL in 1973 working on the area of two phase flow characterization of ammonia and various refrigerants, as well as conducting LOCA studies. In 1980, he joined the ORNL's pellet laboratory where he helped develop and test much of the technology that is currently in use on many pellet injectors around the world. Mr. Combs served on the American Nuclear Society Fusion Energy Division executive committee for many years and was awarded the Outstanding Technical Accomplishment award in 2014 for his work in the area of fusion fueling and disruption mitigation.

Steve J. Meitner - Mr. Meitner is a design and analysis engineer in the Fusion and Materials for Nuclear Systems Division. He graduated from the University of Wisconsin-Madison with a Bachelor of Science in mechanical engineering in 2006 and a Master of Science in mechanical engineering in 2007. He designed, built, and operated an experiment to measure the viscous heat dissipation created by mechanical shear in frozen deuterium, hydrogen, and nitrogen, and calculated shear strength and viscosity properties of deuterium near the triple point. He was hired at ORNL in 2008 and has since been the lead mechanical engineer on various high impact projects within the Fusion and Materials for Nuclear Systems Division. Mr. Meitner has lead the design and development of the high frequency gas gun used for fusion fueling and ELM pacing, the twin screw continuous extruder system, disruption mitigation systems on the DIII-D and JET tokamaks, various components of the Proto-Material Plasma Exposure eXperiment (ProtoMPEX), and many prototype components for the ITER pellet fueling system. 
Dr. Trey E. Gebhart - Dr. Gebhart is a postdoctoral research associate in the Fusion and Materials for Nuclear Systems Division at ORNL. He received Bachelor of Science and a Master of Science in mechanical engineering from Virginia Tech $(2011,2013)$ and completed his Ph.D. in nuclear engineering at the University of Florida (2016). He held a summer internship at ORNL in 2014 where he assisted in developing the method of forming mixed gas pellets for tokamak disruption mitigation. He conducted research on an electrothermal plasma source as a high heat flux source for ELM simulation at ORNL for his dissertation. Since being hired at ORNL, he has assisted in the design, analysis, and testing of various pellet injection technologies. Dr. Gebhart serves as the Technical Program Co-Chair for the 2018 Technology of Fusion Energy conference. He served as the Chair of Virginia Tech's student chapter of the American Nuclear Society between 2011 and 2014.

Charles R. Foust - Mr. Foust is a casual employee in the Fusion and Materials for Nuclear Systems Division at ORNL. He retired from full time service in 2016. Mr. Foust specializes in mechanical design of pellet injector systems and has assisted in the design and assembly of pellet injections systems for fusion experiments around the world.

Tam Ha - Mr. Ha is a lab technician in the Fusion and Materials for Nuclear Systems Division. He assists in the assembly and testing of experiments in ORNL's pellet lab.

Dr. Gary L. Bell - Dr. Gary Bell became the Plasma Technology and Applications Group Leader in April 2013. The group is focused on the development of plasma heating and fueling technologies and the development of capabilities to support the growing area of plasma-materials interaction science.

Gary joined ORNL in 1992 in the Metals and Ceramics Division (M\&C) where he worked on the design and analysis of irradiation experiments on highly enriched uranium coated-particle fuels for High Temperature Gas-Cooled Reactors. He then transferred to the Fusion Energy Division where for 10 years his work included experimental measurements and antenna modeling to advance the application of high power RF heating in magnetic confinement fusion experiments and RF measurement and power delivery system characterization supporting U.S. semiconductor manufacturing. During this time, he served as the Plasma Diagnostics Group Leader at SEMATECH in Austin, TX (2-year off-site assignment).

From 2003-2007 Gary served as the national co-lead for the DOE-NE Advanced Gas Reactor Fuel Development and Qualification Program, leading a multi-directorate ORNL team to develop coated particle fuel for high temperature reactor applications and fabricating fuel that set a new global record for in-core performance. Gary led the ORNL portion of the team that won the 2010 inaugural Gordon Battelle Prize for Technology Impacts - Next Generation Fuel for High Temperature Gas-Cooled Reactors, comprising researchers from ORNL, Idaho National Laboratory, Babcock \& Wilcox, and General Atomics.

Gary established the Nuclear Fuel and Materials Group in the Materials Science and Technology Division in 2005 and served as its group leader until April 2013, with the exception of a 2 year hiatus to work in the Coupled End-to-End Demonstration Project, an integrated test bed for the research, development, and demonstration of nuclear fuel cycle separation and conversion technologies tasked with identifying and resolving interfacial issues between the various steps in the processing of used nuclear fuel. He led the R\&D team that fabricated proof of principle U-Pu-Np oxide fuel pellets using material recycled - without isolating the plutonium - from fuel used at the Dresden Nuclear Power Plant. In his role as the NFM Group Leader, he provided leadership for a variety of nuclear fuel cycle technical and infrastructure projects supporting nuclear fuel and target development, including transmutation fuel feedstock $R \& D$, radioisotope $R \& D$ and production, Tristructural-isotropic coated particle fuel for Light Water Reactor applications, and irradiation testing of advanced fuel materials. 
Gary earned a Doctorate degree in Plasma Physics from Auburn University in 1990. He performed his thesis work (electron cyclotron emission and absorption) at ORNL on the Advanced Toroidal Facility (stellarator) and worked as a post-doctoral researcher on coated particle fuel irradiation testing in ORNL's M\&C Division 1990-1992.

\section{EQUIPMENT, FACILITIES AND OTHER RESOURCES}

The pellet technology program uses the Fusion Pellet Fueling Laboratory located at ORNL in Building 5800, Room D110, Building 7625, Room 108 and Building 7041 for equipment storage. The space charge and utilities are paid from the Fusion and Materials for Nuclear System Division's organization burden account, costing \$70,963 for D110, $\$ 18,161$ for Lab 108, and \$10,196 for space in 7041 in FY2017 (4-year total $\sim$ \$380k). The program has benefitted in recent years from laboratory investments in scroll pumps to replace aging oil roughing pumps, LabView license renewals each year, electrical safety equipment, new test and measurement equipment, and equipment storage cabinets totaling $\$ 107,135$ in FY2014, \$113,725 in FY2015, \$76,007 in FY2016, and 129,643 in FY2017 (4-year total =\$426,510).

Experiments are performed primarily in Rm D110 which contains extensive infrastructure supporting the work described here, including

- Cryocoolers

- Liquid helium and liquid nitrogen dewars and associated safety equipment

- Hydrogen off-gas system and concentration monitoring safety system

- A high-speed pellet test stand

- A variety of test chambers

- Helium leak detectors

- Deionized water cooling system

- Overhead chain hoist

- A variety of vacuum pumps (scroll pumps and turbo pumps)

- Gas distribution system

- Data acquisition and Programmable Logic Control systems

- High speed cameras

- Engineering Analysis Server

- ANYS CFX License

- CREO Licenses

A "fact sheet" describing the laboratory was recently updated and is shown in Fig. 2. 


\section{Fusion Pellet Fueling Laboratory}

\section{Description}

The Fusion Pellet Fueling Laboratory provides test equipment and related diagnostics for carrying out experiments difected at development of pellet injectors for piasma fueling apolications, with recent emphasis on systems for DIII-D and ITER. Several experiments are set $u$ in the lab at any given time. In general, various sized pellets composed of frozen hydrogen isotopes (protium and deuterium) are produced and accelerated with light gases (nydrogen and helium) to speeds of 100 to $3000 \mathrm{~m} / \mathrm{s}$. Cryo-coolers and liquid helium dewars are used routinely to provide the low temperatures $(<20 \mathrm{~K})$ required to freeze solid hydrogen or deuterium from the gas feeds, including continuous extrusions of hydroge? "ice." Most systems also operate under vacuum conditions. Experiments are a so conducted with other frozen gases (e.g., neon or argon) to study the freezing and acceieration processes. In addition to peliet fueling R\&D, experiments are carfied out to support other related fusion technologies, including systems for zas fueling, plasma disruption mitigation, recycling of pellet and propellant gas streams, specialized vacuum pumping applications fe. B., cryo-oumps and other roughing pumps for ITER). A few key systems for ITER are being developed in the lab, with the final systems scheduled to be ready for delivery and installation before the first ITER plasmas.

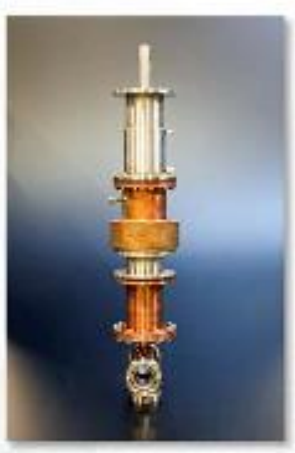

Twin-screw extruder that is being developed for ITER peilet injectors, it will provide a continuous stream of solid hydrogen to mechanisms that will cutichamber and then acceierate pellets (10 to 20 per second at speeds of $-300 \mathrm{~m} / \mathrm{s}$ )
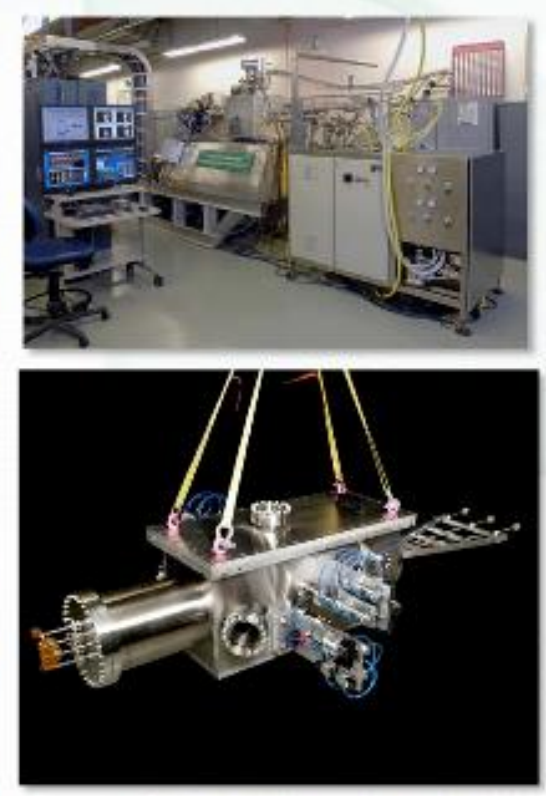

A pellet seiestor for the ITER pellet injection system. It will direct $5 \mathrm{~mm}$ fueling or $3 \mathrm{~mm}$ ELM pasing pellets travelling at $-300 \mathrm{~m} / \mathrm{s}$ from four injestor locations to any three plasma injection iocations.

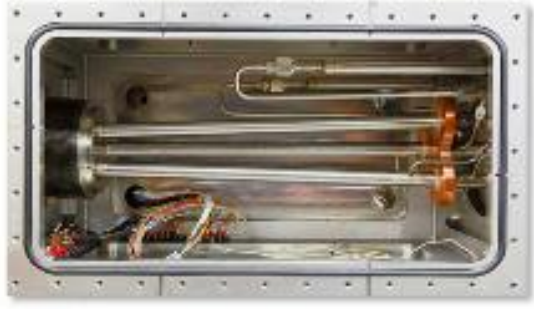

A three - burrel shattered pellet injector for the ITER disruption mitigation system. It will provide pellets with a neon core and a deuterium shell that are shattered into small particies $(<5 \mathrm{~mm}$ ) tefore entering the plasma.

Date: March 2018

CaNt is managed

US Department of Energy

\section{OAK RIDGE}

Tational Laboratory

\section{(D)ENARG}

Fig. 2. Fact sheet describing the Fusion Pellet Fueling Laboratory used to support the work scope authorized by FWP ERAT511 